Maria Kovacova,

Ph.D., University of Zilina, Slovakia

Katarina Valaskova,

Ph.D., University of Zilina, Slovakia

Pavol Durana,

Ph.D., University of Zilina, Slovakia

Jana Kliestikova,

Ph.D., Associate Professor, University of Zilina, Slovakia

\title{
INNOVATION MANAGEMENT OF THE BANKRUPTCY: CASE STUDY OF VISEGRAD GROUP COUNTRIES
}

\begin{abstract}
Since the first bankruptcy prediction models developed in the 60th of 20th century numerous different models have been constructed through the world. These individual models for bankruptcy prediction have been created in different time and space using different methods and variables. During this period various statistical methods have been used starting with the most popular univariate, linear and multivariate discriminant analysis, logistic regression, probit regression, decision trees, neural networks, rough sets, linear programming, principal component analysis, data envelopment analysis, survival analysis and so on. Therefore, we aim to provide deep insight and analyse the bankruptcy prediction models developed in countries of Visegrad four, with the emphasis on methods applied and explanatory variables used in these models, and evaluate them through appropriate statistical methods. Specifically, cluster analysis to explore the differences between basic groups of financial indicators and designed clusters of explanatory variables. Based on the analysis of more than one hundred bankruptcy prediction models we can conclude the most used variables, which serves as a basis for further research and development of prediction models in Visegrad group countries. Three clusters were developed which representing various explanatory variables while these clusters differ from basic groups of financial indicators. According to detected clusters we recommend to choose the most frequently used variables from each created cluster. From the cluster one revenues from sales/total assets ratio; from the cluster two the construction of models should contain current ratio, and from the cluster three we recommend to use ROE. Also if we take into consideration the total frequency together with the constructed clusters we advise to use more variables from clusters two and three. Results of the provided study may be used not only by researchers and enterprises but also by investors during the construction of bankruptcy prediction models in conditions of an individual country.
\end{abstract}

Keywords: bankruptcy, bankruptcy prediction, variables, countries of Visegrad four.

Introduction. Business default can have a variety of forms, different course, results and consequences. The consequences, in particular, are the engine of research and development of methods and models that allow predicting failure with a certain amount of time in advance to know the likely development of business fundamentals over the next few years (Gandolfi et al., 2018). Consequently, mainly because of the globalization and interdependence of individual national economies, the impact of the extinctions and bankruptcies of enterprises is more quantitative than in the past. Individual national economies do not operate alone but rather interact intensively with each other (Balcerzak et al., 2018). Based on this, not only businesses but also the economies of individual countries are increasingly dependent on each other, so a financial crisis of one country can be transferred to another country with a short delay and will soon become global (Ahmad et al., 2018). Business failures can be identified in the literature by different terms, such as the corporate financial health, bankruptcy, financial difficulties, default, credit risk, ex-ante financial analysis, early warning systems, etc. (Svabova et al, 2018). The consequences of failure are the main platform for research and development of methods and models to predict business failure in time, as well as to detect its current financial health. In market economies, these consequences have a direct impact not only on the owners but on all stakeholders involved in the

Cite as: Kovacova, M., Valaskova, K., Durana P. \& Kliestikova, J. (2019). Innovation Management of the Bankruptcy: Case Study of Visegrad Group Countries. Marketing and Management of Innovations, 4, 241 251. http://doi.org/10.21272/mmi.2019.4-19 

Group Countries

interaction with the business (Forgassy et al., 2018). Consequently, the bankruptcy prediction models early warning systems allow to identify the level of the financial health of a company in terms of its past results towards the future. Individual models are based on the assumption that in the development of the company can be found some differences in comparison with financially good companies sometime before the bankruptcy itself. (Popp et al., 2018; Blanton, 2018; Salaga et al., 2015) The prediction of company's failure or the financial health of the enterprise has been researched by various authors for decades, and their efforts to predict the future financial situation of the company have brought a large number of different prediction models. These individual models of financial health prediction were created in different time and space, using various methods and explanatory variables. (Zvarikova et al., 2017) Thus, the main goal of the study is to provide deep insight and analyse the bankruptcy prediction models developed in countries of Visegrad four, with the emphasis on methods applied and explanatory variables used in these models, and evaluate them through appropriate statistical methods. To accomplish given goal of the study, one scientific question was build: Is there any difference between basic groups of financial indicators and designed clusters of explanatory variables used in bankruptcy prediction models of Visegrad group countries?

Literature Review. Since the first and well-known studies of Fitzpatrick (1932), Altman (1968) and Beaver (1966) numerous studies dedicated to the research of bankruptcy prediction of the enterprise have been developed. These are an object of various studies such as Ravi Kumar \& Ravi (2007), Bellovary (2007), Dimitras (1996). These models vary from various perspectives. Each model has been developed in the specific condition of the individual country and environment. Furthermore, the basic data set usually consisted of companies from various economic categories. Thirdly, the main difference is the methodology used for model construction. So, we can conclude that also various explanatory variables were used in these models. Primarily, univariate analysis was used. This was followed by the use of Multiple Discriminant Analysis, which is considered as one of the most popular methods applied for bankruptcy prediction. Another group of popular methods is the application of LOGIT and PROBIT for detection of the probability of default of the company. (Kliestik et al., 2019) These methods were followed by mathematical programming methods, such as Linear Programming (Nath et al., 1992), Data Envelopment Analysis (Ouenniche \& Tone, 2017), Linear Goal Programming (LPG) (Gupta et al., 1990), Multi-Criteria Decision Aid Approach (MCDA) (Zopoudinis \& Doumpos, 1999). On the other side in recent years' popular methods include artificial intelligence (Sion, 2018), like Fuzzy Rules-Based Classification Models (Spanos et al., 1999), Survival Analysis (Luoma \& Laitinen, 1991), Decision Trees (Messier \& Hansen, 1988), Rough Set Analysis (McKee, 2000), Genetic algorithms (Gordini, 2014), Neural networks (Kasgari et al., 2012), Expert systems (Messier \& Hansen, 1988) and Self-organizing maps (SOM) (Kiviluoto, 1998). The research interest focused on countries of Visegrad four. In the Slovak Republic, various methodologies were applied from well-known MDA method, LOGIT and PROBIT method to decision trees, DEA analysis and neural networks (Gurcik, 2002; Delina \& Packova, 2013; Gavurova et al., 2017; Kliestik et al., 2018). In Poland the situation is similar, but there have been developed more than sixty models since nowadays. These models used also mainly MDA, LOGIT, PROBIT, neural networks, but also genetic algorithms, classification trees and survival analysis (Pogodzinska \& Sojak, 1995; Gajdka \& Stos, 1996; Korol, 2004; Pisula et al., 2013; Ptak-Chmielewska, 2016). In Hungary, as in other post-Soviet countries, the problem of corporate insolvency emerged in the early 1990s. In these models except traditional methodologies used in other countries, models applied the techniques of support vector machines and rough set theory. (Hajdu \& Virag, 2001; Virag \& Kristof, 2014; Bauer \& Edrész, 2016). The last country of the Visegrad Group in the Czech Republic. They also constructed models mainly through the use of the abovementioned methods - multiple discriminant analysis, LOGIT, PROBIT, DEA, neural networks (Valecky \& Slivkova, 2012; Karas \& Reznakova, 2013; Vochozka et al., 2015; Nemec \& Pavlik, 2016). 
M. Kovacova, K. Valaskova, P. Durana \& J. Kliestikova. Innovation Management of the Bankruptcy: Case Study of Visegrad Group Countries

These are only a few mentioned models developed in Visegrad group countries. So, based on the above mentioned we aim to provide a deep insight into the bankruptcy prediction models developed in countries of Visegrad four, with the emphasis on explanatory variables used in these models, and evaluate them through cluster analysis to explore the differences between basic groups of financial indicators and designed clusters of explanatory variables.

Methodology and research methods. To accomplish the aim of the presented study we provided a deep review of 103 bankruptcy prediction models developed in countries of Visegrad four, namely Slovak Republic, Hungary, Poland and the Czech Republic with the emphasis on methods used in these models and explanatory variables. After extensive study of bankruptcy prediction models constructed in Visegrad group countries, we have identified 103 models in which all information could be provided (such as research sample, explanatory variables, the method applied, year of development and so on). The collection of all necessary data was the biggest limitation of the presented research, so we had to remove other models with incomplete information. Table 1 shows the number of models in individual countries.

Table 1. Number of prediction models in individual countries

\begin{tabular}{|c|c|c|}
\hline Country V4 & Number of studies & $\%$ \\
\hline Poland & 63 & $61 \%$ \\
\hline Czech Republic & 23 & $22 \%$ \\
\hline Slovak Republic & 11 & $11 \%$ \\
\hline Hungary & 6 & $6 \%$ \\
\hline TOTAL & 103 & $100 \%$ \\
\hline
\end{tabular}

Source: calculated by the authors.

Based on the table we can conclude that the highest number of the analysed models were from Poland.

Cluster analysis allows to sort the objects into clusters so that the objects within a common cluster are from as much similar as possible, objects in different clusters are significantly divergent (Guha et al., 2000). To cluster the explanatory variables used in bankruptcy prediction models in Visegrad group countries, authors use the heuristic-based agglomerative hierarchical method of clustering. The hierarchical method was calculated through Ward's method, which minimizes the heterogeneity of clusters according to the minimum variance criterion. Ward's minimum variance criterion minimizes the total within-cluster variance. At each step, the pair of clusters is found that leads to a minimum increase in total within-cluster variance after merging. (Cygler \& Wyka, 2019) This increase is a weighted squared distance between cluster centres. At the initial step, all clusters are singletons (clusters containing a single point). To apply a recursive algorithm under this objective function, the initial distance between individual objects must be (proportional to) squared Euclidean distance. The initial cluster distances in Ward's minimum variance method are therefore defined to be the squared Euclidean distance between points:

$$
d i j=\sqrt{\sum_{k=1}^{K}(x i k-x j k)^{2}}
$$

where $x_{i k}$ is the value of $k$-th variable of the $i$-th object and $x_{j k}$ is the value of $k$-th variable of the $j$-th object. In the hierarchical approach, we obtain a hierarchical structure of similarities between objects in the form of a tree, called a dendrogram, which illustrates the arrangement of the clusters produced by the analyses. (Ward, 1963).

Results. To accomplish the given aim of the study was necessary first to make a deep insight into the analysed models. As we have mentioned before 103 bankruptcy prediction models of Visegrad group countries were detected and analysed. For the development of these models were used in different statistical methods. Application of these methods in individual countries is revealed in Table 2. 
M. Kovacova, K. Valaskova, P. Durana \& J. Kliestikova. Innovation Management of the Bankruptcy: Case Study of Visegrad Group Countries

Table 2. The method used for the construction of the bankruptcy prediction models

\begin{tabular}{|c|c|c|c|}
\hline Method & Method & Number of studies & $\%$ \\
\hline Discriminant analysis (MDA+LDA+QDA) & DA & 51 & $50 \%$ \\
\hline Conditional probability (Logit+Probit) & CP & 36 & $35 \%$ \\
\hline Neural network (NN+ANN+ANFIS+SOM+FUZZY) & NN & 2 & $2 \%$ \\
\hline Decision trees (Regression Trees+RE-EM+CHAID) & Trees & 2 & $2 \%$ \\
\hline DEA & DEA & 2 & $2 \%$ \\
\hline Others & Other & 10 & $10 \%$ \\
\hline TOTAL & & 103 & $100 \%$ \\
\hline
\end{tabular}

Source: calculated by the authors.

According to Table 2 can be summarized, that researchers prefer to use mainly the linear, multiple and quadratic discriminant analysis. This is followed by conditional probability methods (logit and probit models), neural networks (artificial neural networks, adaptive network-based fuzzy inference system, selforganizing map and fuzzy logic), decision trees (regression trees, RE-EM, CHAID), data envelopment analysis and some other. The proportion of applied methods can be graphically visualized in Figure 1.

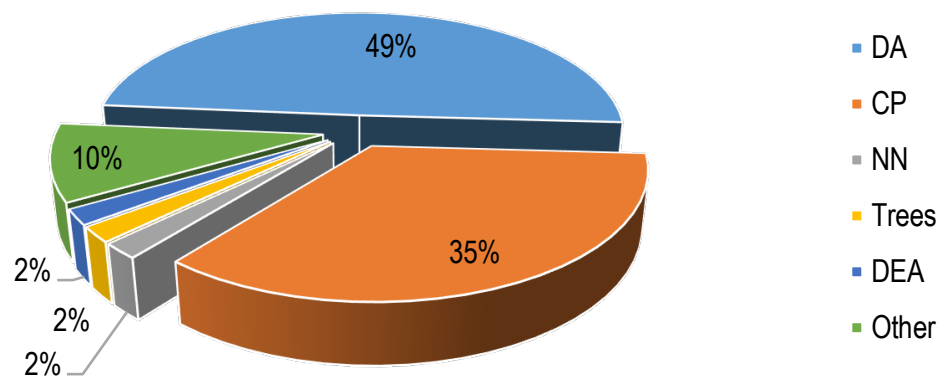

Source: calculated by the authors.

Figure 1. The proportion of used methods

These methods can be associated together as discriminant analysis methods, conditional probability methods and others. So only $16 \%$ of models and studies in these countries used other methods (Table 3 ).

Table 3. The method used for the construction of the bankruptcy prediction models

\begin{tabular}{|c|c|c|}
\hline Method & Number of studies & $\%$ \\
\hline Discriminant analysis & 51 & $50 \%$ \\
\hline Conditional probability & 36 & $35 \%$ \\
\hline Other & 16 & $16 \%$ \\
\hline Total & 103 & $100 \%$ \\
\hline
\end{tabular}

Source: calculated by the authors.

Although, the applied method is an important task of constructed models we aim to focus and highlight the explanatory variables used in these models. Therefore, Table 4 summarizes the number of explanatory variables used in the analysed bankruptcy prediction models of Visegrad group countries.

According to the table, we can determine that it is optimal to use three to seven variables in the final bankruptcy prediction models. Together, there are 507 financial indicators identified in the models. 
M. Kovacova, K. Valaskova, P. Durana \& J. Kliestikova. Innovation Management of the Bankruptcy: Case Study of Visegrad Group Countries

Table 4. Number of explanatory variables used in the bankruptcy prediction models

\begin{tabular}{|c|c|c|c|}
\hline Number of explanatory variables & Number of studies & $\%$ & Total number of explanatory variables \\
\hline 0 & 2 & $2 \%$ & 0 \\
\hline 2 & 9 & $9 \%$ & 18 \\
\hline 3 & 14 & $14 \%$ & 42 \\
\hline 4 & 30 & $29 \%$ & 120 \\
\hline 5 & 14 & $14 \%$ & 70 \\
\hline 6 & 12 & $12 \%$ & 72 \\
\hline 7 & 12 & $12 \%$ & 84 \\
\hline 8 & 4 & $4 \%$ & 32 \\
\hline 9 & 2 & $2 \%$ & 18 \\
\hline 11 & 2 & $2 \%$ & 22 \\
\hline 12 & 1 & $1 \%$ & 12 \\
\hline 17 & 1 & $1 \%$ & 17 \\
\hline TOTAL & 103 & $100 \%$ & $\mathbf{5 0 7}$ \\
\hline
\end{tabular}

Source: calculated by the authors.

Some of them are used almost in every study, especially the ones from the earliest studies, some of them are unique. In the presented research, we focus on those financial ratios, which appear at least 4 times in all models (30 most frequently used ratios in Visegrad group countries). It is important to investigate these explanatory variables in the context of the frequency of their usage in the bankruptcy prediction models in individual countries. This is shown in Table 5.

Table 5. Number of explanatory variables used in the bankruptcy prediction models in individual country

\begin{tabular}{|c|c|c|c|c|c|c|}
\hline Factor & $\begin{array}{c}\text { Czech } \\
\text { Republic }\end{array}$ & Hungary & Poland & $\begin{array}{c}\text { Slovak } \\
\text { Republic }\end{array}$ & Total & Total \% \\
\hline Current ratio & 5 & 0 & 20 & 3 & 28 & $9,21 \%$ \\
\hline Liabilities/Total Assets & 6 & 0 & 17 & 3 & 26 & $8,55 \%$ \\
\hline Quick ratio & 5 & 3 & 10 & 1 & 19 & $6,25 \%$ \\
\hline Equity/Total Assets & 2 & 0 & 13 & 3 & 18 & $5,92 \%$ \\
\hline ROA & 4 & 0 & 11 & 2 & 17 & $5,59 \%$ \\
\hline Cash ratio & 9 & 0 & 6 & 1 & 16 & $5,26 \%$ \\
\hline Working Capital/Total Assets & 3 & 0 & 11 & 2 & 16 & $5,26 \%$ \\
\hline EBIT/Total Assets & 8 & 0 & 2 & 4 & 14 & $4,61 \%$ \\
\hline Operating Profit/Total Assets & 0 & 0 & 12 & 2 & 14 & $4,61 \%$ \\
\hline Cash Flow/Liabilities & 0 & 4 & 8 & 1 & 13 & $4,28 \%$ \\
\hline ROE & 4 & 0 & 8 & 0 & 12 & $3,95 \%$ \\
\hline Total Revenues/Total Assets & 5 & 0 & 6 & 0 & 11 & $3,62 \%$ \\
\hline Total Sales/Total Assets & 4 & 0 & 3 & 3 & 10 & $3,29 \%$ \\
\hline Revenues from Sales/Total Assets & 0 & 0 & 7 & 0 & 7 & $2,30 \%$ \\
\hline $\begin{array}{c}\text { (Current Assets + Accrued } \\
\text { Assets)/(Current Liabilities + Accrued } \\
\text { of Liabilities + Special Funds }\end{array}$ & 0 & 0 & 6 & 0 & 6 & $1,97 \%$ \\
\hline Accrued Revenue) & & & & & & \\
\hline Cash Flow/Total Assets & 1 & 3 & 1 & 1 & 6 & $1,97 \%$ \\
\hline Total Assets/Liabilities & 4 & 0 & 2 & 0 & 6 & $1,97 \%$ \\
\hline EBT from Sales/Operating Costs & 0 & 0 & 6 & 0 & 6 & $1,97 \%$ \\
\hline ROS & 1 & 1 & 2 & 2 & 6 & $1,97 \%$ \\
\hline
\end{tabular}


M. Kovacova, K. Valaskova, P. Durana \& J. Kliestikova. Innovation Management of the Bankruptcy: Case Study of Visegrad Group Countries

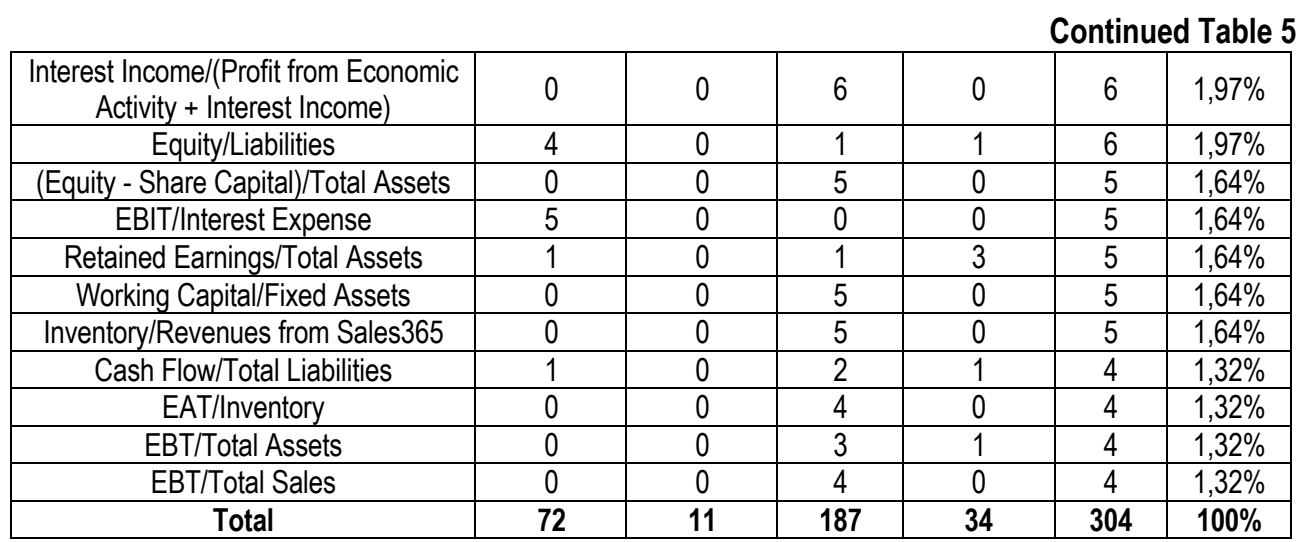

Source: calculated by the authors.

Identified explanatory variables can be arranged also according to the basic groups of financial ratios; ratios of activity, liquidity, profitability and debt. Also according to the cluster analysis, we can compare if the designed clusters match with the basic groups of financial ratios.

Table 6. Explanatory variables with the frequency of their usage in the bankruptcy prediction models

\begin{tabular}{|c|c|c|c|}
\hline Activity Ratios & Frequency & Liquidity Ratios & Frequency \\
\hline Total Revenues/Total Assets & 11 & Current ratio & 28 \\
\hline Total Sales/Total Assets & 10 & Quick ratio & 19 \\
\hline Cash Flow/Total Assets & 6 & Working Capital/Total Assets & 16 \\
\hline $\begin{array}{l}\text { Revenues from Sales/Total } \\
\text { Assets }\end{array}$ & 7 & Cash ratio & 16 \\
\hline $\begin{array}{l}\text { Inventory/Revenues from } \\
\text { Sales*365 }\end{array}$ & 5 & Working Capital/Fixed Assets & 5 \\
\hline & & (Equity - Share Capital)/Total Assets & 5 \\
\hline Total & 39 & Total & 89 \\
\hline Profitability Ratios & Frequency & Debt Ratios & Frequency \\
\hline ROA & 17 & Liabilities/Total Assets & 26 \\
\hline ROE & 12 & Equity/Total Assets & 18 \\
\hline EBIT/Total Assets & 14 & Cash Flow/Liabilities & 13 \\
\hline Operating Profit/Total Assets & 14 & Equity/Liabilities & 6 \\
\hline $\begin{array}{l}\text { EBT from Sales/Operating } \\
\text { Costs }\end{array}$ & 6 & Total Assets/Liabilities & 6 \\
\hline ROS & 6 & $\begin{array}{l}\text { (Current Assets + Accrued Assets)/(Current } \\
\text { Liabilities + Accrued of Liabilities + Special } \\
\text { Funds + Accrued Revenue) }\end{array}$ & 6 \\
\hline $\begin{array}{l}\text { Retained Earnings/Total } \\
\text { Assets }\end{array}$ & 5 & $\begin{array}{c}\text { Interest Income/(Profit from Economic } \\
\text { Activity + Interest Income) }\end{array}$ & 6 \\
\hline EBIT/Interest Expense & 5 & Cash Flow/Total Liabilities & 4 \\
\hline EBT/Total Assets & 4 & & \\
\hline EBT/Total Sales & 4 & & \\
\hline EAT/Inventory & 4 & & \\
\hline Total & 91 & Total & 85 \\
\hline
\end{tabular}

Source: calculated by the authors. 

Group Countries

The results of the analysis presented in table 6 will serve as a basis for the cluster analysis to explore if there are any differences between basic groups of financial indicators and designed clusters of explanatory variables. Based on table 6 we can also sum up that the most important and the most frequently used is the group of profitability ratios, focusing on the assessment of a corporation's ability to generate earnings. This is in the mutual correlation with the bankruptcy prediction, while in most countries the corporate, which doesn't generate earnings, is considered as bankrupt. On the other side, the variable with the highest frequency is the current ratio, which is a liquidity and efficiency ratio that measures a corporation's ability to pay off its short-term liabilities with its current assets. When the corporate is not possible to pay its short term liabilities it signalizes problems. The second most significant variable is the liabilities-to-total-assets ratio, from the group of debt rations. This variable examines how much of a corporation's assets are made of liabilities. It is also a signal for the corporate if the value of this variable is high that there are some potential solvency problems, which may result in the corporate's bankruptcy. Table 6 was a basis for the calculation of the cluster analysis, which results represented in the created dendrogram are presented in Figure 2.

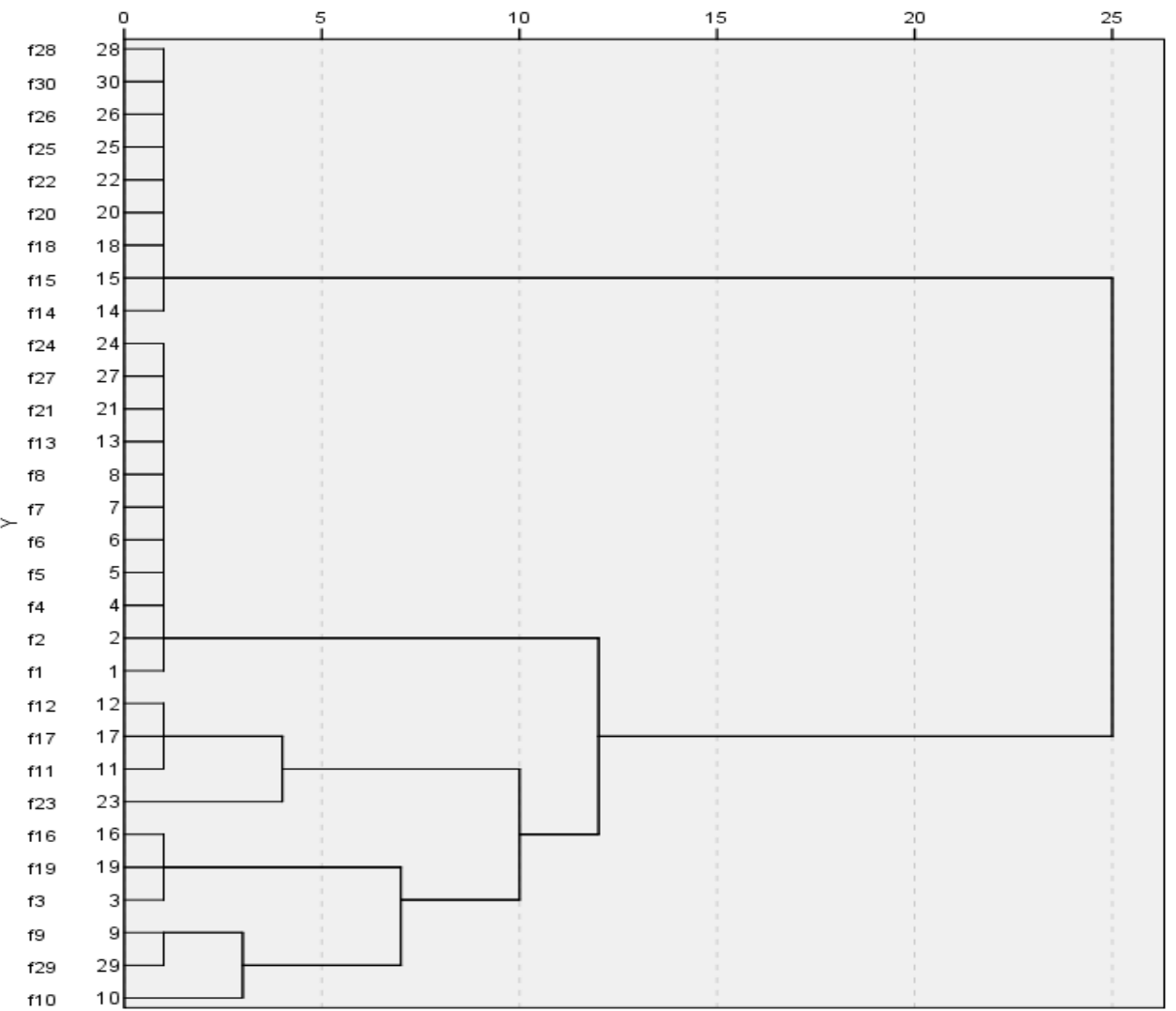

Figure 2. Dendrogram of analysed explanatory variables

Source: calculated by the authors

Dendrogram presents the results of clustering of 30 most frequently used explanatory variables and three main clusters are identified. These are displayed in Table 7. Designed groups of explanatory variables differ from the four basic groups of financial ratios. The final dendrogram reveals only three 
M. Kovacova, K. Valaskova, P. Durana \& J. Kliestikova. Innovation Management of the Bankruptcy: Case Study of Visegrad Group Countries

groups of ratios and these are grouping differently from the original scaling. For the construction of bankruptcy prediction models in Visegrad group countries in the future, we can recommend choosing the most frequently used variables from each created cluster. Therefore, from the cluster one revenues from sales/total assets ratio; (current assets + accrued assets)/(current liabilities + accrued of liabilities + special funds + accrued revenue) ratio; EBT from sales/operating costs ratio; interest income/(profit from economic activity + interest income) ratio.

Table 7. Created clusters of analysed explanatory variables

\begin{tabular}{|c|c|c|c|c|c|}
\hline \multicolumn{2}{|r|}{ Cluster1 } & \multicolumn{2}{|r|}{ Cluster2 } & \multicolumn{2}{|r|}{ Cluster3 } \\
\hline f14 & Revenues from Sales/Total Assets & f1 & Current ratio & f11 & ROE \\
\hline f15 & $\begin{array}{c}\text { (Current Assets + Accrued Assets)/(Current } \\
\text { Liabilities + Accrued of Liabilities + Special } \\
\text { Funds + Accrued Revenue) }\end{array}$ & f2 & Liabilities/Total Assets & f12 & $\begin{array}{l}\text { Total Revenues/Total } \\
\text { Assets }\end{array}$ \\
\hline f18 & EBT from Sales/Operating Costs & f4 & Equity/Total Assets & f17 & Total Assets/Liabilities \\
\hline f20 & $\begin{array}{c}\text { Interest Income/(Profit from Economic } \\
\text { Activity + Interest Income) }\end{array}$ & f5 & ROA & f23 & EBIT/Interest Expense \\
\hline$f 22$ & (Equity - Share Capital)/Total Assets & f6 & Cash ratio & f3 & Quick ratio \\
\hline$f 25$ & Working Capital/Fixed Assets & f7 & $\begin{array}{l}\text { Working Capital/Total } \\
\text { Assets }\end{array}$ & f9 & $\begin{array}{c}\text { Operating Profit/Total } \\
\text { Assets }\end{array}$ \\
\hline$f 26$ & Inventory/Revenues from Sales*365 & f8 & EBIT/Total Assets & $\mathrm{f} 10$ & Cash Flow/Liabilities \\
\hline f28 & EAT/Inventory & f13 & $\begin{array}{l}\text { Total Sales/Total } \\
\text { Assets }\end{array}$ & f16 & Cash Flow/Total Assets \\
\hline $\mathrm{f30}$ & EBT/Total Sales & f21 & Equity/Liabilities & f19 & ROS \\
\hline & & f24 & $\begin{array}{c}\text { Retained } \\
\text { Earnings/Total Assets }\end{array}$ & f29 & EBT/Total Assets \\
\hline & & $\mathrm{f} 27$ & $\begin{array}{c}\text { Cash Flow/Total } \\
\text { Liabilities }\end{array}$ & & \\
\hline
\end{tabular}

Source: calculated by the authors.

Similarly, from the cluster two the construction of models should contain current ratio; liabilities/total assets ratio; equity/total assets ratio; ROA and cash ratio. Finally, from cluster three we recommend to use ROE; total revenues/total assets ratio; total assets/total liabilities ratio; EBIT/interest expense ratio and quick ratio. Also if we take into consideration the total frequency together with the constructed clusters we advise to use more variables from clusters two and three.

Conclusions. The prediction of bankruptcy is an issue of interest of researchers for many years. Various different models containing several explanatory variables and applying dissimilar methods have been constructed. In the presented study we focus only on bankruptcy prediction models developed in the countries of Visegrad four, namely Slovak Republic, Czech Republic, Hungary and Poland. Thus, the main aim of this study was to provide deep insight and analyse the bankruptcy prediction models developed in countries of Visegrad four, with the emphasis on methods applied and explanatory variables used in these models, and evaluate them through appropriate statistical methods. Based on the deep literature review, which we have provided, we have analysed 103 bankruptcy prediction models of Visegrad group countries, focusing on the methodology and explanatory variables used. Applying cluster analysis on these explanatory variables the three clusters were created. Therefore, we can conclude the most used variables, which can serve as a basis for further research and development of prediction models in Visegrad group countries. For the construction of bankruptcy prediction models in Visegrad group countries in the future, we can recommend choosing the most frequently used variables from each created cluster. From the cluster one revenues from sales/total assets ratio; (current assets + accrued assets)/(current liabilities + accrued of liabilities + special funds + accrued revenue) ratio; EBT from 

Group Countries

sales/operating costs ratio; interest income/(profit from economic activity + interest income) ratio. From the cluster two the construction of models should contain current ratio; liabilities/total assets ratio; equity/total assets ratio; ROA and cash ratio. Finally, from cluster three we recommend to use ROE; total revenues/total assets ratio; total assets/total liabilities ratio; EBIT/interest expense ratio and quick ratio. Also if we take into consideration the total frequency together with the constructed clusters we advise to use more variables from clusters two and three. Based on the provided calculations can be summarized that for the development of bankruptcy prediction models in countries of Visegrad four should be used determined groups of explanatory variables. The choice of an appropriate and specific variable in a specific country may be very helpful for enterprises, researchers and investors in the process of construction and development of bankruptcy prediction models in conditions of the individual country.

Author Contributions: conceptualization, M. K. and K. V.; methodology, P. D.; software, P. D.; validation, M. K., K. V. and P. D.; formal analysis, J.K.; investigation, M. K; resources, J. K.; data curation, P. D.; writing-original draft preparation, M. K.; writing-review and editing, M. K. and K. V.; visualization, M. K.; supervision, J. K.; project administration, M. K.; funding acquisition, M. K.

Funding: This work was supported by the science project VEGA 1/0428/17 Creation of new paradigms of financial management at the threshold of the 21st century in conditions of the Slovak Republic and Slovak Research and Development Agency under Grant number APVV-14-0841: Comprehensive Prediction Model of the Financial Health of Slovak Companies.

\section{References}

Ahmad, I., Olah, J., Popp, J., Mate, D. (2018). Does Business Group Affiliation Matter for Superior Performance? Evidence from Pakistan. Sustainability, 10(9):3060

Altman, E. I. (1968). Financial Ratios, Discriminant Analysis and the Prediction of Corporate Bankruptcy. Journal of Finance,

23(4). pp. 589-609.

Balcerzak, A.P., Kliestik, T., Streimikiene, D., Smrcka, L. (2018). Non-Parametric Approach to Measuring the Efficiency of Banking Sectors in European Union Countries. Acta Polytechnica Hungarica, 14(7):51-70.

Bauer, P., Edresz, M. (2016). Modelling Bankruptcy Using Hungarian Firm-Level Data MNB. Budapest, Hungary: Magyar Nemzeti Bank.

Beaver, W. (1966). Financial Ratios as Predictors of Failure. Journal of Accounting Research, 4(3), pp. 71-111.

Bellovary, J. et al. (2007). A Review of Bancruptcy prediction Studies: 1930 to Present. Journal of Financial Education, 33:1-43. Blanton, T. (2018). Convolutional Neural Networks, Analytical Algorithms, and Personalized Health Care: Embracing the Massive Data Analysis Capabilities of Deep Learning Artificial Intelligence Systems to Complement and Improve Medical Services. American Journal of Medical Research, 5(2): 52-57.

Cygler, J., Wyka, S. (2019). Internal barriers to international R\&D cooperation: The case of Polish high tech firms. Forum Scientiae Oeconomia, $7(1): 25-45$

Delina, R., Packova, M. (2013). Prediction bankruptcy models validation in Slovak business environment. E \& M Ekonomie a management, 16(3):101-112.

Dimitras, A.l. et al. (1996). A survey of business failure with an emphasis on prediction method and industrial applications. European Journal of Operational Research, 90: 487-513.

Fitzpatrick, P. (1932). A comparison of ratios of successful industrial enterprises with those of failed firms, Certified Public Accountant, 2:598-605.

Fogarassy, C., Neubauer, E., Mansur, H., Tangl, A., Olah, J., Popp, J. (2018). The main transition management issues and the effects of environmental accounting on financial performance - with focus on cement industry. Administratie si Management Public (31):52-66.

Gajdka, J., Stos, D. (1996). The use of discriminant analysis in assessing the financial condition of enterprises. Restructuring in the Process of Transformation and Development of Enterprises.

Gandolfi, G., Regalli, M., Soana, M.G., Arcuri, M.C. (2018). Underpricing and Long-Term Performance of IPOs: Evidence from European Intermediary-Oriented Markets. Economics, Management, and Financial Markets, 13(3):11-36.

Gavurova, B., Janke, F., Packova, M., Pridavok, M. (2017). Analysis of Impact of Using Trend Variables on Bankruptcy Prediction Models Performance, Ekonomicky Casopis, 65(4):370-383.

Gordini, N. (2014). A genetic algorithm approach for SMEs bankruptcy prediction: Empirical evidence from Italy. Expert Systems with Applications, 41(14):6433-6445. 
M. Kovacova, K. Valaskova, P. Durana \& J. Kliestikova. Innovation Management of the Bankruptcy: Case Study of Visegrad Group Countries

Guha, S., Rastogi, R., Shim, K. (2000). ROCK: A robust clustering algorithm for categorical attributes. Information Systems, 25(5):345-366.

Gupta, Y. et al. (1990). Linear goal programming as an alternative to multivariate discriminant analysis: A note. Journal of Business Finance and Accounting, 17(4):593-598.

Gurcik, L. (2002). G-index - the financial situation prognosis method of agricultural enterprises. Agricultural Economics, 48(8):373-378.

Hajdu, O., Virag, M. (2001). Hungarian Model for Predicting Financial Bankruptcy. Society and Economy in Central and Eastern Europe, 23(12):28-46.

Karas, M., Reznakova, M. (2013). Bankruptcy prediction model of industrial enterprises in the Czech Republic. International Journal of Mathematical Models and Methods in Applied Sciences, 7(5):519-531.

Kasgari, A. A. et al. (2013). Prediction of bankruptcy Iranian corporations through artificial neural network and Pro- bit-based analyses. Neural Computing and Applications, 23(3,4):927-936.

Kiviluoto, K. (1998). Predicting bankruptcies with self organizing map. Neurocomputing, 21:191-201.

Kiestik, T., Kliestikova, J., Kovacova, M., Svabova, L., Valaskova, K., Vochozka, M., Olah, J. (2018). Prediction of financial

health of business entities in transition economies. Addleton Academic Publishers, New York.

Kliestik, T., Valaskova, K., Kliestikova, J., Kovacova, M., Svabova, L. (2019). Bankruptcy prediction in transition economies. EDIS, Zilina. Korol, T. (2004). Assessment of the Accuracy of the Application of Discriminatory Methods and Artificial Neural Networks for the Identification of Enterprises Threatened with Bankruptcy. Gdansk: Doctoral dissertation.

Luoma, M., Laitinen, E.K. (1991). Survival analysis as a tool for company failure prediction. Omega International Journal of Management Science, 19:673-678.

McKee, T.E. (2000). Developing a Bankruptcy Prediction Model via Rough Sets Theory. International Journal of Intelligent Systems in Accounting Finance and Management, 9(3):159-173.

Messier, W.F., Hansen, J.V. (1988). Including rules for expert system development: An example using default and bankruptcy data. Management Science, 34(2):1403-1415.

Nath R. et al. (1992). A Comparison of the Classical and the Linear Programming Approaches to the Classification Problem in Discriminant Analysis. Journal of Statistical Computation and Simulation, 41:73-93.

Nemec, D., Pavlik, M. (2016). Predicting Insolvency Risk of the Czech Companies. International Scientific Conference Quantitative Methods in Economics (Multiple Criteria Decision Making XVIII), Bratislava, Slovakia, 258-263.

Ouenniche, J., Tone, K. (2017). An out-of-sample evaluation framework for DEA with application in bankruptcy prediction Annals of Operations Research, 254(1-2):235-250.

Pisula, T., Mentel, G., Brozyna, J. (2013). Predicting Bankruptcy of Companies from the Logistics Sector Operating in the Podkarpacie Region. Modern Management Review 18: 113-133.

Pogodzinska, M., Sojak, S. (1995). The Use of Discriminant Analysis in Predicting Bankruptcy of Enterprises. Ekonomia XXV, Zeszyt 299. Torun: AUNC

Popp, J., Olah, J., Machova, V., Jachowicz, A. (2018). Private equity market of the Visegrad group. Ekonomicko-manazerske spektrum, 12(1):1-15.

Ptak-Chmielewska, A. (2016). Statistical Models for Corporate Credit Risk Assessment-Rating Models. Acta Universitatis Lodziensis Folia Oeconomica 3:98-111.

Ravi Kumar, P., Ravi, V. (2007). Bankruptcy prediction in banks and firms via statistical and intelligent techniques-A review European. Journal of Operational Research, 180(1):1-28.

Salaga, J., Bartosova, V., Kicova, E. (2015). Economic Value Added as a measurement tool of financial performance, Procedia Economics and Finance, 26:484-489.

Sion, G. (2018). How Artificial Intelligence Is Transforming the Economy. Will Cognitively Enhanced Machines Decrease and Eliminate Tasks from Human Workers through Automation? Journal of Self-Governance and Management Economics, 6(4):31-36.

Spanos, M. et al. (1999). A fuzzy knowledge-based decision aiding method for the assessment of financial risk: the case of corporate bankruptcy prediction. European Symposium on Intelligent Techniques (ESIT), 1-7.

Svabova, L., Kramarova, K., Durica, M. (2018). Prediction model of firm's financial distress, Ekonomicko-manazerske spektrum,

12(1):16-29

Valecky, J., Slivkova, E. (2012). Microeconomic Scoring Model of Czech Firms' Bankruptcy. Ekonomicka Revue, 15(1):15-26.

Virag, M., Kristof, T. (2014). Is there a trade-off between the predictive power and the interpretability of bankruptcy models?

The case of the first Hungarian bankruptcy prediction model. Acta Oeconomica, 64(4):419-440.

Vochozka, M. Strakova, J., Vachal, J. (2015). Model to Predict Survival of Transportation and Shipping Companies. Nase More

Special Issue, 62:109-113.

Ward, J.H. (1963). Hierarchical grouping to optimize an objective function, Journal of the American Statistical Association 58:236-244.

Zopounidis, C., Doumpos, M. (1999). A multicriteria aid methodology for sorting decision problems: The case of financial distress. Computational Economics, 14:197-218.

Zvarikova, K., Spuchlakova, E., Sopkova, G. (2017). International comparison of the relevant variables in the chosen bankruptcy models used in the risk management, Oeconomia Copernicana, 8(1):145-157. 
M. Kovacova, K. Valaskova, P. Durana \& J. Kliestikova. Innovation Management of the Bankruptcy: Case Study of Visegrad Group Countries

Марія Ковакова, Ph.D., Жилінський університет (Словаччина):

Катаріна Валаскова, Ph.D., Жилінський університет (Словаччина);

Павол Дурана, Ph.D., Жилінський університет (Словаччина);

Яна Клісстікова, Ph.D., доцент, Жилінський університет (Словаччина).

Інноваційні підходи в управлінні банкрутством: приклад країн Вишеградської четвірки

Авторами визначено, що перші моделі діагностики банкротства були розроблені у 60-х роках XX століття. При цьому набір змінних, що були характерними для конкретного випадку діагностики банкрутства. Так, використовувались статистичні методи одновимірного, лінійного та багатовимірного дискримінантного аналізу, моделі логістичної регресії, пробіт-регресії, дерева рішень, нейронних мереж, неточних множин, лінійного програмування, метод основних компонентів, аналізу зведених даних тощо. У статmі проаналізовано та систематизовано основні моделі діагностики ймовірності банкрутства, що застосовувались в країнах Вишеградської групи, з виокремленням основних пояснювальних змінних. Авторами здійснено кластерний аналіз з метою вивчення відмінностей між основними групами фрінансових показників та розробленими кластерами пояснювальних змінних. На основі результатів аналізу понад ста моделей прогнозування банкрутства сформовано систему змінних, що стало основою для подальщих досліджень та розробок моделей прогнозування в країнах Вишеградської групи. У статті сформовано три кластери, що включають різні пояснювальні змінні, що відрізняються від основних груп фрінансових показників. Відповідно до виявлених кластерів, запропоновано систему змінних. Так, з першого кластеру виокремлено наступні показники: коефріцієнт доходу від продажу/загальних активів. 3 другого кластеру: показники співвідношення, а відповідно з третього кластеру показники ROE. Крім цього встановлено, що найчастіше на практиці використовують показники з кластеру два та три. Авторами наголошено, що отримані результати дослідження можуть бути використані не тільки дослідниками та підприємствами, але й інвесторами при побудові моделі прогнозування банкрутства в умовах окремої країни.

Ключові слова: банкрутство, прогнозування банкрутства, змінні, країни Вишеградської групи.

Manuscript received: 20.05.2019.

(C) The author(s) 2019. This article is published with open access at Sumy State University. 